Acta vet. scand. $1986,27,497-504$.

From the Division of Furbearing animals and the Department of Virology, National Veterinary Institute, Uppsala, Sweden.

\title{
AVIAN INFLUENZA A VIRUS CAUSING AN OUTBREAK OF CONTAGIOUS INTERSTITIAL PNEUMONIA IN MINK
}

By

L. Englund, B. Klingeborn and T. Mejerland

\begin{abstract}
ENGLUND, L., B. KLINGEBORN and T. MEJERLAND: Avian influenza A virus causing an outbreak of contagious interstitial pneumonia in mink. Acta vet. scand. 1986, 27, 497-504. - An outbreak of contagious respiratory disease in mink occurred in October 1984 on the south-east coast of Sweden. High morbidity with coughing, sneezing and dullness was reported. Post mortem examination showed interstitial pneumonia in most examined mink. An avian influenza A virus was isolated and shown to belong to serotype H1ON4. Serological studies established that this virus was the most probable cause of the outbreak and also that this new viral infection seemed to be limited to the south-east coast of Sweden.
\end{abstract}

lung; ELISA; contagious pneumonia.

Contagious viral infections causing pneumonia in mink are known from studies of distemper (Bindrich et al. 1959) and aleutian disease associated parvovirus infections (Alexandersen 1985). In the case of distemper, pneumonia is one of many characteristical findings, also including symptoms such as conjunctivitis, rhinitis, paresis/paralysis and hyperaemia and swelling of the paws (Bindrich et al. 1959). The interstitial pneumonia caused by parvovirus infection has so far been found only in young mink kits under special immunological conditions (Alexandersen 1985). This article describes the first known outbreak of pneumonia caused by avian influenza $A$ virus infection in mink. The outbreak involving 33 farms, occurred in October 1984 in a concentrated farm area ("Listerlandet") on the south-east coast of Sweden (Klingeborn et al. 1985). 


\section{MATERIAL AND METHODS}

\section{Pathological investigation}

During a 6 week period, 54 dead mink from the affected farms were sent to the National Veterinary Institute for post mortem examination. Lung tissue specimens from all mink were fixed in $10 \%$ formaldehyde, embedded in paraffin, cut and stained with haematoxylin and eosin (HE) for light microscopic examination.

\section{Virological and bacteriological investigations}

Ten per cent solutions of lung tissue specimens from $6 \mathrm{mink}$ from 5 different farms were prepared in phosphate-buffered saline (PBS) and inoculated into the amniotic sack of 11 day old chicken embryos for virus isolation. Amniotic fluids were harvested after $48 \mathrm{~h}$ of incubation at $37^{\circ} \mathrm{C}$, the procedure being described in detail elsewhere (Klingeborn et al. 1985). Lung tissue specimens from all mink were also cultured aerobically on horse-blood agar and lactose agar at $37^{\circ} \mathrm{C}$ overnight. Identification of bacteria was performed by conventional methods (Cowan 1974).

\section{Serological investigation}

Thirty $(3 \times 10)$ serum samples from 3 affected farms and 15 $(5+10)$ from 2 unaffected farms were collected in the end of of November 1984. All sera were tested by haemagglutinationinhibition (HI) test against 2 influenza virus isolates, the method for the investigation described earlier (Klingeborn et al. 1985). In the end of March 1985, approximately 5 months after the outbreak, a total of 2891 sera were collected, all from male, adult mink. Most samples (2400) were collected from 24 farms within the area where the outbreak had occurred. As a comparison 491 serum samples from 7 mink farms in other parts of the country were examined (Fig. 1). All sera were investigated by ELISAtechnique using the isolated virus strain as antigen (see below).

The ELISA method used to detect antibody to H1ON4 was mainly developed as described recently (Juntti et al. submitted for publication). In short, the mink influenza virus was propagated and purified as described previously for equine influenza virus (Abusugra et al. 1985). The purified virus was used at a 


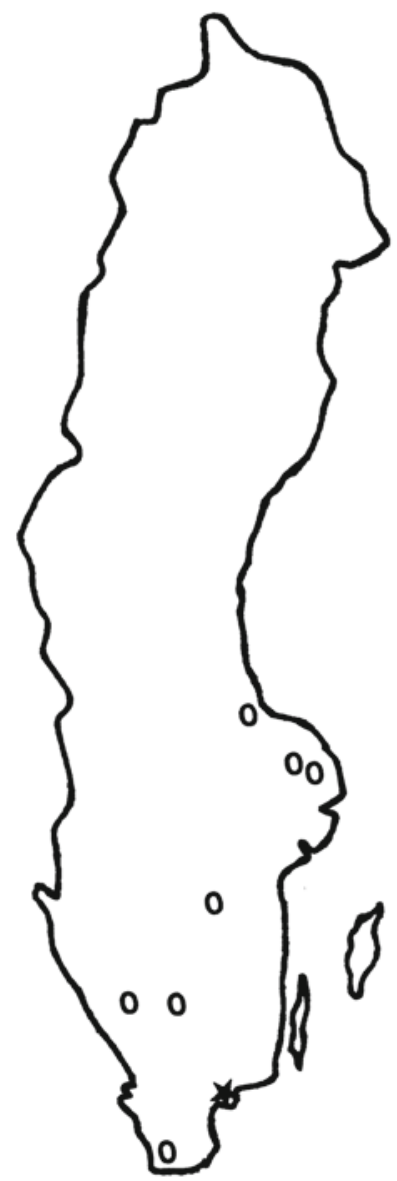

Figure 1. Map of Sweden. $\star=$ area where the outbreak occurred, $\mathbf{O}=$ other farm, investigated serologically.

protein concentration of $3 \mu \mathrm{g} / \mathrm{ml}$ in $0.05 \mathrm{mmol} / 1$ sodium barbonate buffer containing $0.1 \% \mathrm{NaN}_{3}, \mathrm{pH} 9.6$, and $100 \mu \mathrm{l}$ was added per well of polystyrene microtiter plates (Nunc, Denmark). The plates were sealed and stored at $-20^{\circ} \mathrm{C}$. After washing the plates twice with phosphate-buffered saline with $0.1 \%$ Tween 20 (PBST), $100 \mu$ of each serum diluted 1:40 and 1:200 in PBS-T containing $1 \%$ bovine serum albumin was added to 1 well per dilution and incubated for $1 \mathrm{~h}$ at $37^{\circ} \mathrm{C}$. The plates were washed twice with PBS-T and $100 \mu \mathrm{l}$ of staphylococcus protein A conjugated with horseradish peroxidase diluted 1:1000 was added. After incubation for $1 \mathrm{~h}$ at $37^{\circ} \mathrm{C}$, the plates were waṣhed twice wịth 
PBS-T and $200 \mu \mathrm{l}$ of substrate solution $(0.1 \mathrm{mg} / \mathrm{ml}$ of tetramethylbenzidin (TMB) and $0.05 \% \mathrm{H}_{2} \mathrm{O}_{2}$ in $0.1 \mathrm{M} \mathrm{NaAc}$ buffer, $\mathrm{pH}$ 6.0) was added to the wells. After $10 \mathrm{~min}$ at room temperature $50 \mu \mathrm{l}$ of $5 \mathrm{mmol} / \mathrm{I} \mathrm{H}_{2} \mathrm{SO}_{4}$ was added to stop the reaction. The absorbance at $450 \mathrm{~nm}$ was measured on a Titertek microplate reader (Flow Lab., Irvine) and the antibody titers were calculated by use of an TI66 programable calculator (Texas Instruments). For positive result the cutoff value of 0.5 was used.

\section{RESULTS}

\section{Clinical and pathological findings}

Signs of respiratory disease, first occurring around October 1st, were reported from the affected mink farms. The most frequent symptoms were severe coughing, sneezing, dullness and in the most affected animals also anorexia. All ages of both male and female mink were showing similar symptoms. No differences in susceptibility between different mink types were observed. A nonspecific treatment with tylosine-tartrate and -phosphate (Tylan ${ }^{\circledR}$ Vet., Elanco, Lilly Ind. Ltd., England) $10 \mathrm{mg}$ per $\mathrm{kg}$ body weight mixed in the feed for 4-day periods weekly for 3 weeks beginning in the middle of October, resulted in a reduced number of mink dying, but did not seem to arrest the spread of the disease within the farms. The morbidity rate was estimated to be close to $100 \%$ and the farmers reported deaths of around 4000 mink which gives a mortality rate of roughly $2.5 \%$. The last deaths due to pneumonia were reported in the middle of November. Forty-four of the examined mink showed macroscopical signs of pneumonia, multifocal areas of consolidation and hyperaemia in all lung lobes. Microscopical examination of the fixed lung tissue specimens gave the results shown in Table 1. The interstitial pneumonia, which represents more than $50 \%$

T a b le 1. Microscopical findings in the lungs of 54 mink submitted to examination during the outbreak of respiratory disease in 1984 .

\begin{tabular}{lc}
\hline Diagnosis & No. of cases \\
\hline Interstitial pneumonia & 29 \\
Purulent/necrotic bronchopneumonia & 8 \\
Other findings (i.e. oedema, hyperaemia) & 9 \\
Not investigated (autolytic material) & 8 \\
\hline
\end{tabular}


L. Englund, B. Klingeborn and T. Mejerland: Avian Influenza A Virus Causing an Outbreak of Contagious Interstitial Pneumonia in Mink.

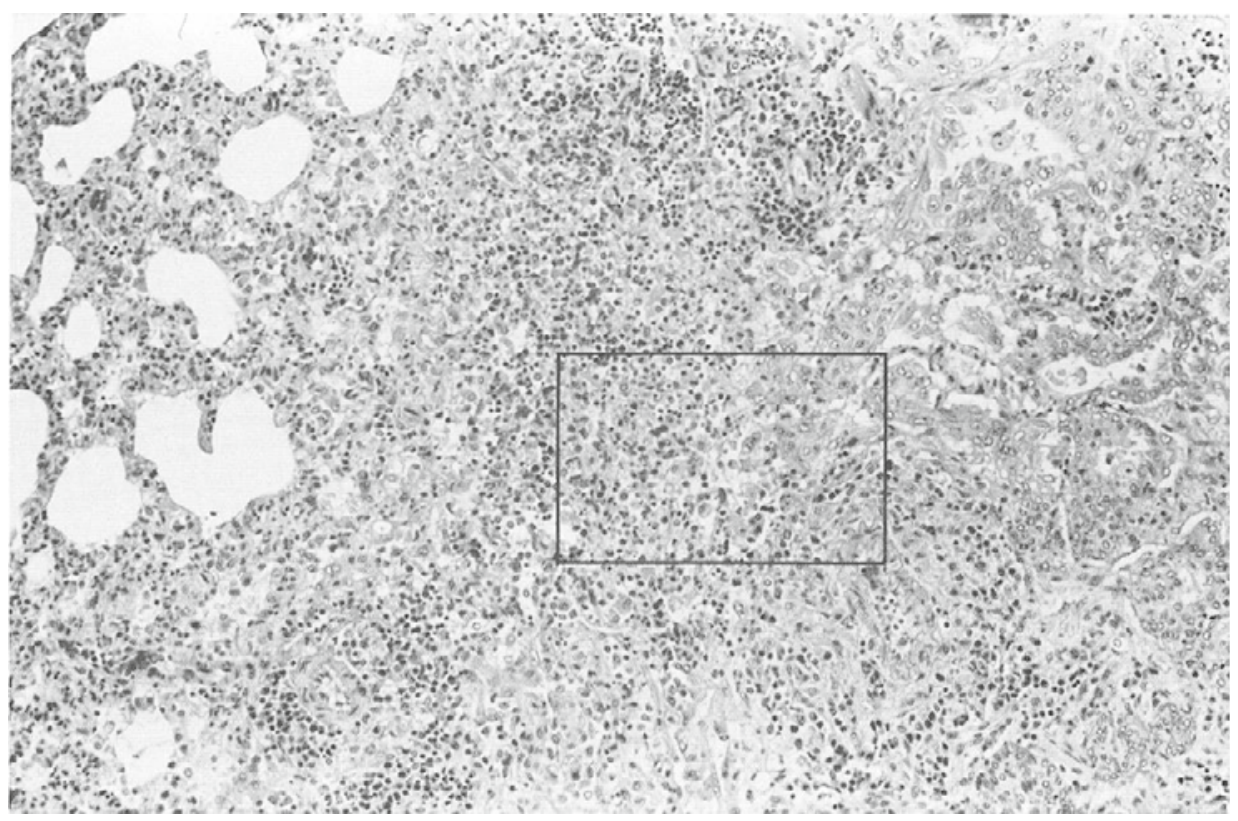

Figu re 2 a. Interstitial pneumonia. Mink dead during influencalike outbreak. Note proliferation of alveolar epithelium and occurrence of macrophages and lymphocytes. HE. $\times 110$.

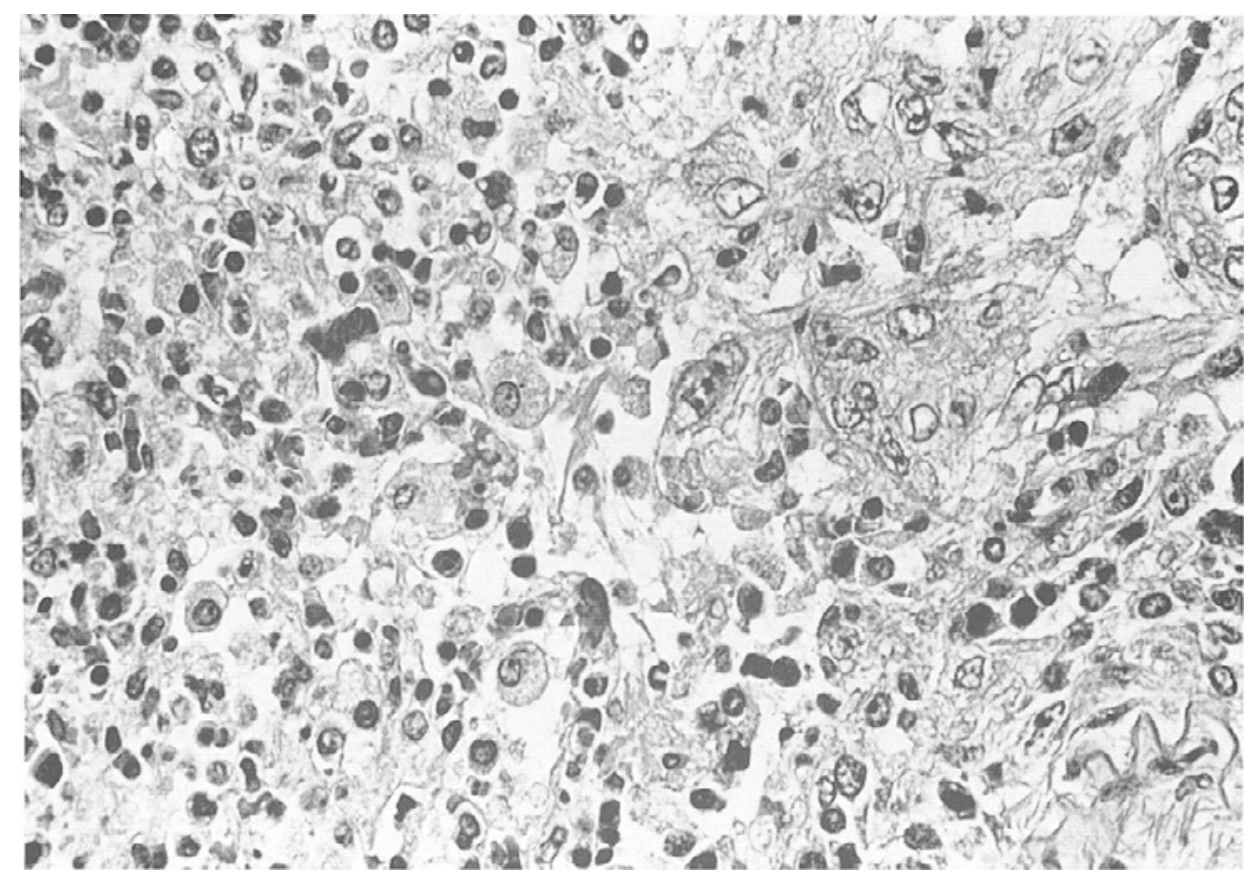

Fig u re 2 b. Close up of Fig. 2a. HE. $\times 430$. 

of the cases, was characterized by proliferation of the alveolar epithelial cells together with masses of desquamated epithelial cells and macrophages in the alveolar lumina. A marked infiltration of macrophages and lymphocytes, forming cuffs around the blood vessels and invading the interalveolar septa was frequently seen (Fig. 2).

\section{Virological findings}

Five identical virus strains were isolated from lung material from 5 different farms in the affected area. The virus was found to be an avian influenza $A$ virus of serotype H1ON4 and subsequently named $\mathrm{A} / \mathrm{mink} / \mathrm{Sweden} / 84$, as previously described by Klingeborn et al. (1985).

\section{Bacteriological findings}

The bacteriological investigation showed growth of bacteria in lungs from 39 mink. In most cases (24) E. coli was found but also $\beta$-hemolytic streptococci ( 7 cases), Pasteurella multocida 3 cases), coagulase positive staphylococci ( 3 cases), Proteus spp ( 1 case) and Actinobacillus spp (1 case) were isolated.

\section{Serological findings}

Twenty-four out of 30 of the sera collected from affected farms in November 1984 were found positive when tested for antibodies to the 2 virus isolates used. None of the 15 sera callected from farms not involved in the outbreak showed any positive reaction (Klingeborn et al. 1985). In the 24 farms, within the affected area, investigated 5 months after the outbreak an average of $57 \%$ of the animals in each farm were found positive for antibodies to $\mathrm{H} 1 \mathrm{ON} 4$. No positive reactors were found in any of the 7 farms in other parts of Sweden.

\section{DISCUSSION}

The clinical findings and the sudden onset of the outbreak of respiratory disease gives an inclination of a contagious disease. Since only respiratory signs were observed in all farms the possibility of it being a distemper outbreak is small (Bindrich et al. 1959, Liu \& Coffin 1957). Interstitial pneumonia caused by parvovirus infection is also less likely due to the widespread differences in age of affected animals, although the microscopical 
findings can be similar (Alexandersen 1985). The third known contagious pneumonia in mink with clinical findings reminding of those seen during the outbreak is hemorrhagic pneumonia caused by Pseudomonas aeruginosa. This highly contagious disease can be ruled out completely since the pathological findings are characterized by acute hemorrhagic-purulent bronchopneumonia (Knox 1953, Nordstoga 1968) and the agent, Pseudomona aeruginosa, is usually easily isolated from various organs, including lungs (Knox 1953, Karlsson et al. 1971). The clinical and pathological findings are more similar to those seen in connection with influenza infections in other species, including homo (Shope 1931, Blumenfeldt et al. 1959, Louria 1959, Gerber 1969). The fact that the outbreak continued in spite of the tylosine treatment supports the theory that the observed bacterial infections are probably secondary to a viral infection. The influence of the bacterial infections on the mortality is still to be investigated in this case but from studies in other species, including homo, bacterial infections are known to complicate the course of influenza infections (Louria et al. 1959, Gerber 1969).

The mortality rate of $2.5 \%$ given here is a rough estimate based on figures submitted by individual farmers and by 2 involved insurance companies. It does, however, indicate a rise of mortality in the affected farms during the outbreak. The "normal" losses are around $\mathbf{0 . 1 5} \%$ per week, which gives a total of $0.9 \%$ during the observed 6 -weeks period (unpublished observations). The isolation of 5 identical avian influenza $A$ virus strains from 5 different affected farms in combination with the result of the first serological investigation show that the probable cause of the described outbreak is the isolated influenza virus, namely $\mathrm{A} / \mathrm{mink} / \mathrm{Sweden} / 84$, H1ON4. The serological investigation performed 5 months after the outbreak supports our belief that the infections were limited to the farms on the southeast coast of Sweden. The choice of farms and animals examined were however based mainly on volontary efforts by individual, interested farmers, and therefore the results can only be considered as an indication and not as a definite, unbiased result. The theory presented earlier (Klingeborn et al. 1985) that seabirds could have been the original source of the influenza virus, H1ON4, has been strengthened by isolations of avian influenza A virus, serotype $\mathrm{H} 1 \mathrm{ON} 4$, from feral mallards in Great Britain in March 1985 (Alexander \& Gough 1986). Studies to investigate 
the relation between this isolate and $\mathrm{A} / \mathrm{mink} / \mathrm{Sweden} / 84$ will be performed. Comprehensive studies are also performed to further describe the pathogenesis and the nature of this new viral disease of mink.

\section{REFERENCES}

Abusugra, A. J., T. Linné, B. Klingeborn \& Z. Dinter: Influenza Equi 2: Patterns of RNA and protein in variant strains. Zbl. Vet. Med. B $1985,32,567-574$.

Alexander, D. J. \& R. E. Gough: Isolations of avian influenza virus from birds in Great Britain. Vet. Rec. 1986, 118, 537-538.

Alexandersen, S.: Eksperimentelle unders $\varnothing$ gelser vedrørende infektion med aleutian disease virus hos mink med særligt henblik på akut interstitiel pneumoni hos hvalpe. (Experimental studies on infection with aleutian disease virus in mink with special reference to acute interstitial pneumonia in kits). Licentiatafhandling. Inst. for veterinær patologi, Den kgl. Veterinær- og Landbohøjskole, Danmark 1985.

Bindrich, H., E. Kuwert, $H$. Linsert \& H. Zimmermann: Zur Staupeerkrankung der Nerzes. (On distemper in mink). Arch. Exp. Vet. Med. 1959, 13, $1-25$.

Blumenfeldt, H. L., E. D. Kilbourne, D. B. Louria \& D. E. Rogers: Studies on influenza in the pandemic of 1957-1958. I. An epidemiologic, clinical and serological investigation of an intrahospital epidemia, with a note on vaccination efficacy. J. clin. Invest. 1959, 38, 199-212.

Cowan, S. T.: Cowan and Steel's Manual for Identification of Medical Bacteria. 2nd Ed., Cambridge Univ. Press, Cambridge 1974.

Gerber, H.: Clinical features, sequelae and epidemiology of equine influenza. In Proc. 2nd Int. Conf. Equine Infectious Diseases, Paris 1969. Karger, Basel/München/New York 1970, p. 63-80.

Karlsson, K.-A., K.-E. Kull \& R. Svanholm: Infektion med Pseudomonas aeruginosa hos mink. Infektions- och Vaccinationsförsök. (Infections in mink caused by Pseudomonas aeruginosa. Infection and vaccination trials). Nord. Vet.-Med. 1971, 23, 345-351.

Klingeborn, B., L. Englund, R. Rott, N. Juntti \& G. Rockborn: An avian influenza A virus killing a mammalian species - the mink. Arch. Virol. 1985, 86, 347-351.

Knox, B.: Pseudomonas aeruginosa som årsag till enzootiske infektioner hos mink. (Pseudomonas aeruginosa as a cause of enzootic infections in mink). Nord. Vet.-Med. 1953, 5, 731-760.

Liu, C.\& D. L. Coffin: Studies on canine distemper infection by means of fluoresceine-labeled antibody. 1. The pathogenesis pathology and diagnosis of the disease in experimentally infected ferrets. Virology 1957, 3, 115-131. 
Louria, D. B., H. L. Blumenfeldt, J. T. Ellis, E. D. Kilbourne \& D. E. Rogers: Studies on influenza in the pandemic of 1957-58. II. Pulmonary complications of influenza. J. clin. Invest. 1959, 38, 213-265.

Nordstoga, K.: Pseudomonas infections in mink with special reference to pseudomonas vasculitis in pulmonary lesions. Acta vet. scand. $1968,9,33-40$.

Shope, R. E.: Swine influenza. 1. Experimental transmission and pathology. J. exp. Med. 1931, 54, 349—359.

\section{SAMMANFATTNING}

Aviärt influensa A virus som orsak till ett utbrott av smittsam interstitiell pneumoni hos mink.

Ett utbrott av smittsam respiratorisk sjukdom hos mink uppträdde i oktober 1984 i ett begränsat område (Listerlandet) i sydöstra Sverige. Hög morbiditet med hosta, nysningar och andningsproblem rapporterades. Obduktion visade en interstitiell pneumoni av proliferativ typ hos de flesta undersökta minkarna. Ett aviärt influenza A virus isolerades och visades tillhöra serotyp H1ON4. Serologiska undersökningar visade att detta virus var den sannolika orsaken till utbrottet samt att denna för mink nya virusinfektion verkade vara begränsad till Listerlandet.

(Received July 4, 1986).

Reprints may be requested from: L. Englund, the Division of Furbearing Animals, Nationàl Veterinary Institute, P. O. Box 7073, S-750 07 Uppsala, Sweden. 